
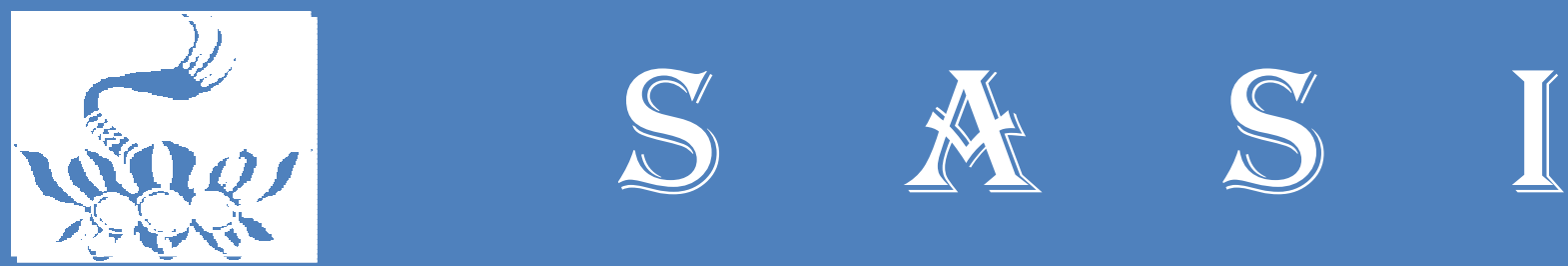

Jurnal Ilmiah Fakultas Hukum Universitas Pattimura Ambon

- Peralihan Hak Cipta Kepada Ahli Waris Menurut Hukum Perdata Muchtar A. H. Labetubun dan Sabri Fataruba

- Tanggungjawab Pengusaha Pelayaran Dalam Perjanjian Kerja Laut (PKL) Terkait Dengan Jam Kerja

Agustina Balik

- Upaya Hukum Pembatalan Putusan Arbitrase Di Pengadilan Pieter Radjawane

- Kriteria Badan Usaha Milik Negara yang Diberikan Hak Monopoli dalam Perspektif Hukum Persaingan Usaha

Rory J. Akyuwen

- Pemenuhan Hak Asasi Manusia Atas Bangunan Dengan Kontrak Built, Operate And Transfer

Sarah S. Kuahaty

- Penyelesaian Sengketa Hak Atas Tanah Masyarakat Hukum Adat Adonia Ivonne Laturette

- Perlindungan Korban Kejahatan Dalam Hukum Positif Indonesia Hb. Sujiantoro

- Kerugian Negara dalam Pemberiaan Pinjaman Dana Bergulir Bagi Koperasi Simpan Pinjam

J. Hattu

- Pemidanaan Anak dalam Perspektif Keadilan Restoratif Hadibah Zachra Wadjo 


\section{PE N GE L O LA}

\begin{tabular}{|c|c|c|c|}
\hline Penanggung Jawab & $:$ & Dr. J. Tjiptabudy, SH. M. Hum & (Dekan) \\
\hline \multirow[t]{4}{*}{ Penasihat } & : & 1. J. D. Pasalbessy, SH. M.Hum & (PD I) \\
\hline & & 2. Dr. A. D. Laturete, SH. MH & (PD II) \\
\hline & & 3. N. Tianotak, SH. M.Hum & (PD III) \\
\hline & & 4. O. Lawalata, SH. M.Hum & (PD IV) \\
\hline Pemimpinan Redaksi & : & Ny. S. S. Kuahaty, SH. MH & \\
\hline Wakil Pemimpin Redaksi & $:$ & Ny. R. D. Daties, SH. MH & \\
\hline Sekretaris Redaksi & $:$ & E. S. Holle, SH. MH & \\
\hline \multirow[t]{4}{*}{ Redaksi Ahli } & $:$ & 1. Prof. Dr. R. Z. Titahelu, SH. MS & \\
\hline & & 2. Dr. H. Hattu, SH. MH & \\
\hline & & 3. Dr. J. Leatemia, SH. MH & \\
\hline & & 4. Dr. S. E. M. Nirahua, SH. M.Hum & \\
\hline \multirow[t]{4}{*}{ Redaktur Pelaksana } & $:$ & 1. Ny. Y. A. Lewerissa, SH. MH & \\
\hline & & 2. M. A. H. Labetubun, SH. L.LM & \\
\hline & & 3. A. D. Bakarbessy, SH. LLM & \\
\hline & & 4. S. Peilouw, SH. MH & \\
\hline
\end{tabular}




\section{EDITORIAL}

Pemerintah dalam melaksanakan tugasnya, sering diperhadapkan dengan perubahan yang terjadi dalam masyarakat. Dinamika dan tuntutan masyarakat yang begitu cepat berubah, ternyata menimbulkan berbagai permasalahan hukum, termasuk masalah tanggungjawab pemerintah dalam memberikan perlindungan sesuai dengan tugas dan tanggungjawab serta kewenangannya. Dalam edisi "SASI" kali ini beberapa permasalahan hukum yang menjadi sorotan adalah Peralihan Hak Cipta Kepada Ahli Waris Menurut Hukum Perdata, Tanggungjawab Pengusaha Pelayaran Dalam Perjanjian Kerja Laut (PKL) Terkait Dengan Jam Kerja, Upaya Hukum Pembatalan Putusan Arbitrase Di Pengadilan, Kriteria Badan Usaha Milik Negara yang Diberikan Hak Monopoli dalam Perspektif Hukum Persaingan Usaha, Pemenuhan Hak Asasi Manusia Atas Bangunan Dengan Kontrak Built, Operate And Transfer, Penyelesaian Sengketa Hak Atas Tanah Masyarakat Hukum Adat, Perlindungan Korban Kejahatan Dalam Hukum Positif Indonesia, Kerugian Negara dalam Pemberiaan Pinjaman Dana Bergulir Bagi Koperasi Simpan Pinjam, Pemidanaan Anak dalam Perspektif Keadilan Restoratif.

Pemikiran-pemikiran yang dikembangkan di atas sebenarnya didasarkan pada kajian-kajian yang terkait dengan upaya pengembangan dan pembangunan ilmu hukum kedepan, semoga tulisan-tulisan ini bermanfaat. 


\section{DAFTAR ISI}

Editorial

Daftar Isi

- Peralihan Hak Cipta Kepada Ahli Waris Menurut Hukum Perdata Muchtar A. H. Labetubun dan Sabri Fataruba

- Tanggungjawab Pengusaha Pelayaran Dalam Perjanjian Kerja Laut (PKL) Terkait Dengan Jam Kerja

Agustina Balik

- Upaya Hukum Pembatalan Putusan Arbitrase Di Pengadilan

Pieter Radjawane

- Kriteria Badan Usaha Milik Negara yang Diberikan Hak Monopoli dalam Perspektif Hukum Persaingan Usaha

Rory J. Akyuwen

- Pemenuhan Hak Asasi Manusia Atas Bangunan Dengan Kontrak Built, Operate And Transfer

Sarah S. Kuahaty

- Penyelesaian Sengketa Hak Atas Tanah Masyarakat Hukum Adat Adonia Ivonne Laturette

- Perlindungan Korban Kejahatan Dalam Hukum Positif Indonesia Hb. Sujiantoro

- Kerugian Negara dalam Pemberiaan Pinjaman Dana Bergulir Bagi Koperasi Simpan Pinjam

J. Hattu

- Pemidanaan Anak dalam Perspektif Keadilan Restoratif Hadibah Zachra Wadjo

Ketentuan Penulisan Jurnal SASI 


\section{KETENTUAN PENULISAN JURNAL SASI}

Jurnal SASI adalah jurnal ilmiah yang diterbitkan oleh Fakultas Hukum Universitas Pattimura, sebagai upaya mempublikasikan hasil-hasil pemikiran dan penelitian di bidang ilmu hukum dalam upaya pengembangan ilmu hukum, dengan ketentuan sebagai berikut:

1. Naskah Tulisan bertemakan hukum, bersifat ilmiah yang belum pernah diterbitkan dalam media cetak lain.

2. Sistematika penulisan terdiri dari Abstrak, Pendahuluan, Pembahasan, Penutup, dan Daftar Pustaka

3. Naskah wajib mencantumkan abstrak dalam bentuk bahasa Inggris yang baik.

4. Diketik dengan menggunkan pengolah kata MS Word, spasi rangkap, setebal 10-15 halaman kwarto dalam bentuk naskah dan disket.

5. Margin kiri dan atas 4, margin kanan dan bawah 3. Menggunakan huruf Times New Roman 12.

6. Redaksi berhak menyingkat atau memperbaiki tulisan untuk keseragaman format tanpa mengubah maksud isinya. kandungan tulisan tetap menjadi tanggungjawab penulis. 
Rory J. Akyuwen, Kriteria Badan Usaha.

\title{
KRITERIA BADAN USAHA MILIK NEGARA YANG DIBERIKAN HAK MONOPOLI DALAM PERSPEKTIF HUKUM PERSAINGAN USAHA
}

\author{
Oleh: Rory J. Akyuwen
}

\begin{abstract}
Analysuing the position of monopoly State-Owned Enterprises in the perspective of business competition law which could potentially give rise to barriers in business competition in particular concerning control over production branches are considered important and master his life much. Though it is excluded in law number 5 of 1999 concerning the prohibition of Monopolies and Anticompetitive Business practices are unhealthy, but that should not be considered a monopoly owned by the State-Owned Enterprises at the same time have the power over the market, and all the power over its own market not obliging him to carry on the practice of healthy competition.

Criteria for State-Owned Enterprises can be given a monopoly in business competition law perspective, just look at the functions and Government intervention in the economy aimed at the earliest possible time the prosperity of the people. Criteria for State-Owned Enterprises can be given a monopoly should be seen from the form and objectives of the establishment of State-Owned Enterprises as well as the magnitude of the ownership of the Government's stake in it.
\end{abstract}

Keyword: Criteria State Owned Enterprises, Monopoly

\section{A. PENDAHULUAN.}

Di dalam alinea ke empat Pembukaan UUD NRI 1945, telah dirumuskan secara jelas peranan Negara dibidang perekonomian yaitu:

“.....melindungi segenap bangsa Indonesia dan seluruh tumpah darah Indonesia dan untuk memajukan kesejahteraan umum, mencerdaskan kehidupan bangsa dan ikut melaksanakan ketertiban dunia yang berdasarkan kemerdekaan, perdamaian abadi dan keadilan sosial".

Di sini jelas bahwa tujuan membentuk Negara Republik Indonesia adalah untuk memperbaiki struktur ekonomi dan menegakan sendi-sendi perekonomian nasional. Disebutkan pula dalam Pembukaan UUD NRI 1945 bahwa untuk membentuk pemerintahan (kursif penulis) adalah untuk memajukan kesejahteraan sekelompok rakyat Indonesia saja. ${ }^{1}$

Selanjutnya, berdasarkan Pasal 33 UUD NRI 1945, menjelaskan kedudukan pemerintah dalam pembangunan ekonomi memikul tanggung jawab besar dalam mewujudkan peran hukum dalam kegiatan ekonomi. Dalam sistem ekonomi pasar sekalipun (market economy) kegiatan ekonomi tidak dapat sepenuhnya diserahkan kepada mekanisme pasar, berdasarkan permintaan dan penawaran, melainkan juga diserahkan kepada pemerintah untuk mengatur, mengawasi jalannya ekonomi dengan memakai instrument hukum adminstrasi Negara yang umum maupun khusus.

Hal tersebut di atas mengacu pada kerangka teori tentang campur tangan Negara dalam bidang perekonomian, khususnya pengaturan pasar dalam konsep Negara kesejahteraan (welfare state). Dalam

\footnotetext{
${ }^{1}$ Marthen Arie. Op Cit, hal 42
} 
govemment in which the state assumes responsbillity for minimum standards of living for every person" (bentuk pemerintahan di mana Negara dianggap bertanggungjawab untuk menjamin standar hidup minimum bagi setiap warganya. ${ }^{2}$

Penting untuk dipahami bahwa dalam mekanisme kekuasaan, negara merupakan representasi dari kedaulatan publik. Tujuan campur tangan Negara tidak lain adalah untuk meningkatkan kesejahteraan umum dan memaksimalkan kesejahteraan sosial sehingga memperkecil dampak kegagalan pasar terhadap masyarakat yang disebabkan oleh apa yang disebut Moral hazard dan penggunaan yang keliru terhadap berbagai sumber daya. ${ }^{3}$

Selanjutnya, menurut Goodin ${ }^{4}$ dalam Negara kesejahteraan campur tangan Negara dalam mengatur pasar dilukiskannnya sebagai "...a public intervention in private market economy". Tujuannya tidak lain adalah guna meningkatkan kesejahteraan umum (promoting public welfare) dan memaksimumkan kesejahteraan sosial (to maximize social welfare) sehingga memperkecil dampak kegagalan pasar (market failure) terhadap masyarakat yang disebabkan oleh apa yang disebutnya moral hazard dan penggunaan yang keliru terhadap berbagai sumber daya (misallocation of resources). Dalam hal ini, cukup penting apa yang dikemukakan oleh Oscar Lafontaine ${ }^{5}$, "krisis di Asia Timur seperti yang pernah terjadi di Meksico sebelumnya menunjukan bahwa pasar tidak bisa menyelesaikan segalanya. Sebaliknya, pasar yang tidak dikontrol menyebabkan perkembangan negatif sehingga semua orang di dunia harus membayarnya dengan kehilangan yang sangat besar, termasuk kehilangan mata

2 Johnny Ibrahim Op Cit, hal 32

3 Jimmly Asshiddiqie, 2005, 2008,2010, Konstitusi dan Konstitusionalisme Indonesia, Menuju Negara Hukum yang Demokratis, Konstitusi Ekonomi, Konstitusi Pers, PT Kompas Media Nusantara, Jakarta. hal. 406

4 Ibid

5 Ibid pencahariannya".

Selanjutnya Goodin menambahkan nilai-niali yang harus dijaga dalam menghadapi perilaku pasar bebas,

"the market has a corrosive of fect on values', debasing what was formerly precious and a part form mundane world, by allowing everything to be exchange for everything else. In the end we are left with nothing but a 'vending machine society' where everything is available for a price. ${ }^{6}$

Dari uraian Goodin di atas dapat disimpulkan bahwa pasar memiliki dampak yang merusak nilai-nilai, merendahkan derajat terhadap apa yang sebelumnya mulia dan telah dianggap sebagai kebiasaan, yaitu jika membiarkan segala sesuatu dapat dipertukarkan dengan segala sesuatu yang lainnya. Pada akhirnya, kita ditinggalkannya bukan sebagai apa-apa, tetapi hanya sebagai masyarakat yang menjadi mesin penjual, dimana segalanya tersedia hanya dalam satu harga

Tanpa campur tangan pemerintah (dalam konteks Negara kesejahteraan), menurut Goodin lebih lanjut

"Under the law of the market, those who are dependent could and would be mercilessly exploited. Economically, you can drive a very hard bargain indeed and dependent upon you for satisfaction of that need. Morally, however you must do not so".

Di bawah aturan pasar, mereka-mereka yang bergantung pada yang lainnya, akan sangat mudah dieksploitasi tanpa belas kasihan sama sekali. Secara ekonomi anda dapat saja mengusahakan penawaran yang terbaik terhadap siapapun yang membutuhkan dan bergantung pada anda untuk memenuhi kebutuhan tersebut. Namun secara moral tindakan tersebut tidak dapat dibenarkan. Dalam hubungan inilah maka pengaturan di luar kebiasaan pasar dimaksudkan untuk melindungi ekspolitasi terhadap mereka-mereka yang memiliki 
ketergantungan tersebut sehinga ketergantungan itu tidak dapat dimanfaatkan oleh pihak yang lebih kuat untuk kepentingan mereka, tetapi untuk melindungi mereka yang lemah .

Di sinilah fungsi negara sebagai penyedia untuk memenuhi standar minimal yang diperlukan masyarakat dalam rangka mengurangi dampak pasar bebas yang dapat merugikan masyarakat. Selanjutnya untuk menjamin ketertiban agar tidak muncul kekacauan, seperti halnya pengaturan di bidang investasi agar industri dapat tumbuh dan berkembang, pengaturan dan pembatasan terhadap ekspor dan impor agar tersedia devisa yang cukup guna menunjang kegiatan perdagangan, maka fungsi negara sebagai pengatur diperlukan campur tangan langsung dari pemerintah dalam perekonomian sebagai pelaku usaha melalui BUMN, karena ada bidang usaha tertentu yang vital bagi masyarakat, namun tidak menguntungkan bagi usaha swasta, atau usaha yang berhubungan dengan kepentingan pelayanan umum harus dilaksanakan. Bahkan sebagai penegak hukum, Negara akan menjaga ketertiban dan keadilan denganh mengeluarkan berbagai produk aturan hukum dan mengawasi pelaksanaannya.

Pemerintah dalam Negara kesejahteraan diberi tugas membangun kesejahteraan umum dalam berbagai bidang. ${ }^{7}$ Pemerintahan tidak boleh pasif atau berlaku sebagai " penjaga malam", melainkan harus aktif masyarakat dengan cara membangun kehidupan ekonomi dan sosial masyarakat. Dengan demikian, tugas negara tidak terbatas dalam memelihara tatatertib serta melindungi jiwa dan harta kekayaan rakyatnya, melainkan juga negara bertugas mewakili kepentingan bersama, meningkatkan kemakmuran yg adil dan merata, atau dalam melaksanakan tugasnya negara mempunyai kewajiban memerhatikan kepentingan bersama.

7 Astim Riyanto, 2000, Teori konstitusi, Yapemdo, Bandung, hal 280.
Seperti telah disebutkan sebelumnya, Negara melakukan campur tangan dalam bidang ekonomi melalui BUMN. Wacana campur tangan negara adalah wacana aktualisasi kerja BUMN yang dengan demikian berarti negara dalam konteks campur tangan dibidang ekonomi sama dengan BUMN. Dalam kerangka normatif UU BUMN menyebutkan bahwa:

"Badan Usaha Milik Negara, yang selanjutnya disebut BUMN, adalah badan usaha yang seluruh atau sebagian besar modalnya dimiliki oleh negara melalui penyertaan secara langsung yang berasal dari kekayaan negara yang dipisahkan".

BUMN adalah salah satu bentuk usaha yang memengang peranan lebih karena dikelola oleh pemerintahan untuk mencapai tujuan yang di maksud di atas. BUMN terdiri atas tiga bentuk yakni Perusahaan Persero, Perusahaan Persero Terbuka dan Perusahaan Umum.

Dalam kaitannya dalam pemberian hak monopoli bagi BUMN merupakan bukti bahwa fungsi dan campur tangan dari negara dan dunia usaha sangat di perlukan bagi kesejahteraan masyarakat sehinga dalam persaingan usaha tidak berdampak negatif bagi pelaku usaha maupun masyarakat sebagai konsumen.

Penulis sependapat dengan konsep Negara Kesejahteraan yang pada dasarnya menempatkan negara dalam setiap aspek kehidupan rakyatnya demi terwujudnya kesejahteraan sosial bagi seluruh rakyat. Negara kesejahteraan merupakan bagian dari masyarakat modern yang sejalan dengan ekonomi kapitalis dan stuktur politik demokratis. Konsep ini dipandang sebagai bentuk keterlibatan negara mengenai kegagalan pasar pada masyarakat kapitalis dan kegagalan negara pada masyarakat sosialis. Namun dalam konteks Indonesia tetap berbeda karena campur tangan pemerintah atau negara dalam perekonomian tidak serta merta menghilangkan peran swasta. Swasta tetap diberi peran sepanjang 
kegiatan usahanya tidak menguasai hajat hidup orang banyak dan penting bagi negara

\section{B. PEMBAHASAN}

\section{Kriteria Badan Usaha Milik Negara Yang Diberi Hak Monopoli}

Menurut Susi Susanti Adi Nugroho ${ }^{8}$

bahwa pengecualian bagi BUMN seyogianya dilakukan secara bersyarat, dengan kriteria-kriteria yang harus dipenuhi BUMN sebelum memegang hak monopoli, seperti harus professional dan transparan. Ada dua kriteria yuridis yang harus dipenuhi BUMN atau lembaga lainnya untuk mendapatkan hak monopoli tersebut, yaitu:

1) Barang dan/atau jasa yang dihasilkan harus menguasai hajat hidup orang banyak dan masuk dalam cabangcabang produksi yang penting bagi Negara.

2) Keharusan diaturnya hal tersebut dalam bentuk undang-undang.

Ketentuan Pasal 51 UU Anti Monopolimengatur mengenai monopoli dan/atau pemusatan kegiatan yang berkaitan dengan produksi dan/atau pemasaran barang dan/ atau jasa yang menguasai hajat hidup orang banyak serta cabang-cabang produksi yang penting bagi Negara, di mana untuk itu perlu diatur dengan undang-undang dan diselengarakan oleh badan usaha milik Negara dan/atau badan atau lembaga yang dibentuk atau ditunjukan oleh pemerintah.

Ketentuan Pasal 51 UU Anti Monopoli dapat diuraikan dan dijelaskan dalam beberapa unsur sebagai berikut:

1) Monopoli dan/atau pemusatan kegiatan.

2) Produksi dan/atau pemasaran barang dan/atau jasa yang menguasai hajat hidup orang banyak.

3) Cabang-cabang produksi yang penting bagi Negara.

8 Susi Susanti Adi Nugroho, 2012, Hukum Persaingan Usaha Di Indonesia Dalam Teori Dan Praktik Serta Penerapan Hukumnya, Kencana Prenada media Group, Jakarta, 2012, hal 65
4) Diatur dengan undang-undang.

Diselenggarakan oleh Badan Usaha Milik Negara (BUMN) dan/atau badan atau lembaga yang dibentuk atau ditunjuk oleh pemerintah.

\section{a. Monopoli dan/atau Pemusatan Kegiatan}

Unsur monopoli Pasal 51 UU Anti Monopoli dapat mengacu pada definisi dalam Pasal 1 angka 1 UU Anti Monopoli yaitu: "Penguasaan atas produksi dan/atau pemasaran barang dan/atau atas penggunaan jasa tertentu oleh satu pelaku usaha atau satu kelompok pelaku usaha”. Berdasarkan definisi tersebut, pada dasarnya monopoli menggambarkan suatu keadaan penguasaan pelaku usaha atas barang dan/atau jasa tertentu, yang dapat dicapai tanpa harus melakukan ataupun mengakibatkan terjadinya praktik monopoli dan/atau persaingan usaha tidak sehat.

Adapun unsur pemusatan kegiatan dalam Pasal 51 UU Anti Monopoli dapat didefinisikan sebagai pemusatan ekonomi sebagaimana dimaksud yaitu "Penguasaan yang nyata atas suatu pasar bersangkutan oleh satu atau lebih pelaku usaha sehingga dapat menentukan harga barang dan/atau jasa". Berdasarkan definisi tersebut, pemusatan kegiatan pada dasarnya menggambarkan suatu keadaan penguasaan yang nyata atas suatu pasar bersangkutan yang dicerminkan dari kemampuannya dalam menentukan harga yang dapat dicapai oleh satu atau lebih pelaku usaha tanpa harus melakukan ataupun mengakibatkan terjadinya praktik monopoli dan/atau persaingan usaha tidak sehat.

Dengan memperhatikan uraian pemahaman unsur-unsur tersebut di atas, maka baik monopoli maupun pemusatan kegiatan bukan merupakan kegiatan yang dilarang UU Anti Monopoli, dan dapat dilakukan ataupun dicapai oleh satu atau lebih pelaku usaha dengan tetap memerhatikan prinsip-prinsip persaingan usaha yang sehat. Monopoli dan/atau pemusatan kegiatan dapat dilakukan Negara 
terhadap kegiatan yang berkaitan dengan:

1) Produksi dan/atau pemasaran barang dan/atau jasa yang menguasai hajat hidup orang banyak dan,

2) Cabang-cabang produksi yang penting bagi Negara

b. Produksi dan/atau Pemasaran Barang dan/atau Jasa yang Menguasai Hajat Hidup Orang Banyak

Berdasarkan teori hukum dan penafsiran sistematis terhadap unsur ini, maksud barang dan/atau jasa yang menguasai hajat hidup orang banyak adalah memiliki fungsi: ${ }^{9}$

a) Alokasi, yang ditujukan pada barang atau jasa yang berasal dari sumber daya alam yang dikuasai Negara untuk dimanfaatkan bagi sebesar-besarnya kemakmuran rakyat.

b) Distribusi, yang diarahkan pada barang dan/atau jasa yang dibutuhkan secara pokok oleh masyrakat, tetapi pada suatu waktu tertentu tau terus menerus tidak dapat dipenuhi pasar; dan/atau

c) Stabilitasi, yang berkaitan dengan barang dan/atau jasa yang harus disediakan untuk kepentingan umum, seperti barang dan/atau jasa dalam bidang pertahanan keamanan, moneter, dan fiskal, yang mengharuskan pengaturan dan pengawasan yang bersifat khusus.

\section{c. Cabang-cabang Produksi yang} Penting Bagi Negara

Pengertian cabang-cabang produksi yang penting bagi Negara adalah ragam usaha produksi atau penyediaan barang dan/atau jasa yang memiliki sifat:

a) Strategis, yaitu cadang produksi atas barang dan/atau jasa yang secara langsung melindungi kepentingan pertahanan Negara dan menjaga keamanan nasional; atau b) Finansial, yaitu cabang produksi yang berkaitan erat dengan pembuatan barang dan/atau jasa untuk kestabilan moneter dan jaminan perpajakan dan sektor jaksa keuangan yang dimanfaatkan untuk kepentingan umum.

Monopoli dan/atau pemusatan kegiatan oleh Negara terhadap kegiatan yang berkaitan dengan produksi dan/atau pemasaran barang dan/atau jasa yang menguasai hajat hidup orang banyak serta cabang-cabang produksi yang penting bagi Negara harus dialur dengan undang-undang.

\section{d. Diatur dengan Undang-Undang}

Pengertian diatur dengan undangundang merupakan syarat legal dari Negara untuk melakukan monopoli dan/atau pemusatan kegiatan atas barang dan/atau jasa yang menguasai hajat hidup orang banyak serta cabang-cabang produksi yang penting bagi Negara. Hal ini berarti monopoli dan/atau pemusatan kegiatan serta mekanisme pengendalian dan pengawasan Negara dalam penyelenggaraan monopoli dan/atau pemusatan kegiatan tersebut, sehingga tidak mengarah pada praktik monopoli dan/atau persaingan usaha tidak sehat.

\section{e. Diselenggarakan oleh Badan Usaha Milik Negara (BUMN) dan/atau Badan atau Lembaga yang Dibentuk atau Ditunjuk oleh Pemerintah}

Unsur "Badan Usaha Milik Negara" dapat mengacu pada Pasal 1 angka 1 UU BUMN adalah "Badan usaha yang seluruh atau sebagian besar modalnya dimiliki oleh Negara melalui penyertaan secara langsung yang berasal dari kekayaan Negara yang dipisahkan". Penyelenggaraan monopoli dan/atau pemusatan kegiatan produksi dan/atau pemasaran barang dan/atau jasa oleh Negara terhadap kegiatan yang berkaitan dengan produksi dan/atau pemasaran atas barang dan/atau jasa yang menguasai hajat hidup orang banyak sefrta cabang produksi yang penting bagi Negara, 
diutamakan dan terutama diselenggarakan oleh BUMN.

Keberadaan Badan Usaha Milik Daerah (BUMD) adalah tidak sama dan tidak termasuk dalam ruang lingkup dari pengertian badan usaha milik negara. Hal ini disebabkan pengaturannya yang bersifat khusus dan tata cara pendirian dan pertanggungjawabannya diatur berbeda sesuai dengan peraturan perundangundangan tersendiri yaitu yang terkait dengan pemerintah daerah.

Dalam hal BUMN tidak memiliki kemampuan utnuk menyelenggarakan penguasaan monopoli Negara, maka berdasarkan Pasal 51 UU Anti Monopoli, penyelenggaraan monopoli dan/atau pemusatan kegiatan dapat diselenggarakan oleh badan atau lembaga yang dibentuk pemerintah.

\section{f. Unsur "Diselenggarakan Badan atau Lembaga yang Dibentuk Pemerintah"}

Pemerintah dalam pengertian peraturan perundang-undangan adalah pemerintah pusat yang terdiri atas presiden dan seluruh aparatur administrasi Negara tingkat pusat. Dengan demikian, badan atau lembaga yang dibentuk pemerintah adalah badan atau lembaga yang ditetapkan dan diatur dengan peraturan perundangundangan yang dibentuk pemerintah pusat. Badan atau Lembaga yang dibentuk pemerintah menjalankan tugas pelayanan kepentingan umum (public service) yang kewenangannya berasal dari pemerintah pusat dan dibiayai oleh dana Negara (APBN) atau dana publik lainnya yang memiliki keterkaitan dengan Negara. Badan atau Lembaga yang dibentuk pemerintah memiliki ciri melaksanakan:

(1)Pemerintahan Negara;

(2)Manajemen keadministrasian Negara;

(3)Pengendalian atau penguasaan terhadap badan usaha milik Negara dan/atau tata usaha Negara.

Badan atau lembaga yang dibentuk pemerintah dalam menyelenggarakan monopoli dan/atau pemusatan kegiatan, wajib memenuhi hal-hal sebagai berikut:

(1)Pengelolaan dan pertanggungjawaban kegiatannya dipengaruhi, dibina, dan dilaporkan kepada pemerintah;

(2)Tidak semata-mata ditujukan untuk mencari keuntungan;

(3)Tidak memiliki kewenangan melimpahkan seluruh atau sebagian monopoli dan/atau pemusatan kegiatan kepada pihak lain.

BUMN dan badan atau lembaga yang dibentuk pemerintah dapat menyelenggarakan monopoli dan/atau pemusatan kegiatan secara bersama-sama sesuai dengan kebutuhan dan pertimbangan berdasarkan peraturan perundang-undangan. Dalam hal BUMN, badan atau lembaga yang dibentuk pemerintah tidak memiliki kemampuan untuk menyelenggarakan monopoli dan/atau pemusatan kegiatan, maka pemerintah dapat menunjuk badan atau lembaga tertentu.

\section{g. Unsur "Diselenggarakan Badan atau Lembaga yang Ditunjuk Pemerintah"}

Badan atau lembaga yang ditunjuk oleh pemerintah memilki ruang lingkup yang luas, termasuk di dalamnya adalah badan atau lembaga perdata yang tidak memiliki keterkaitan dengan tugas dan fungsi Negara. Menurut teori hukum administrasi Negara, penunjukan adalah kewenangan dari pejabat administrasi Negara yang berwenang bersifat penetapan untuk menyelenggarakan atau menjalankan kegiatan tertentu secara sepihak. Dengan demikian, badan atau lembaga yang ditunjuk pemerintah adalah badan atau lembaga yang ditetapkan oleh pejabat administrasi Negara yang berwenang.

Prosedur dan persyaratan penunjukan badan atau lembaga yang ditunjuk pemerintah sebagai penyelenggara monopoli dan/atau pemusatan kegiatan yang dimaksud, dilakukan berdasarkan peraturan perundang-undangan yang mengatur mengenai pengadaan barang dan/atau jasa pemerintah, sehingga tidak mengakibatkan 
terjadinya monopoli dan persaingan usaha tidak sehat.

BUMN dan badan atau lembaga yang ditunjuk oleh pemerintah dapat menyelenggarakan monopoli dan/atau pemusatan kegiatan secara bersama-sama sesuai kebutuhan dan pertimbangan berdasarkan peraturan perundang-undangan. BUMN ataupun badan atau lembaga yang dibentuk ataupun ditunjuk oleh pemerintah sebagai penyelenggara monopoli dan/atau pemusatan kegiatannya baik sebagian maupun seluruhnya kepada pihak lain.

Dengan memerhatikan uraian tersebut di atas, maka terkait dengan penyelenggara monopoli dan/atau pemusatan kegiatan dan/atau jasa yang menguasai hidup orang banyak, serta cabang produksi yang penting bagi Negara, Pasal 51 UU Anti Monopoli, menentukannya secara sistematis dengan tetap mendasarkan pada alasan-alasan yang rasional berupa pertimbangan profesionalitas, legalitas, dan efektivitas pencapaian sasaran, tujuan penyelenggaraan monopoli dan/atau pemuasatan kegiatan.

Secara sistematis sesuai dengan Pasal 51 UU Anti Monopoli, urut-urutan yang dapat dijadikan acuan bagi pemerintah untuk menentukan pihak penyelenggara monopoli dan/atau pemusatan kegiatan yang berkaitan dengan produksi dan/atau pemasaran barang dan/atau jasa yang menguasai hajat hidup orang banyak serta cabang produksi yang penting bagi Negara adalah sebagai berikut:

(1) Diselenggarakan oleh BUMN.

(2) Diselenggarakan oleh BUMN dan badan yang dibentuk pemerintah.

(3) Diselenggarakan oleh BUMN dari lembaga yang dibentuk pemerintah.

(4) Diselenggarakan oleh badan hyang dibentuk pemerintah.

(5) Diselenggarakan oleh lembaga yang dibentuk pemerintah.

(6) Diselenggarakan oleh BUMN dan badan yang ditunjuk pemerintah.

(7) Diselenggarakan oleh BUMN dan lembaga yang ditunjuk pemerintah.

(8) Diselenggarakan oleh badan yang ditunjuk pemerintah.
(9) Diselenggarakan oleh lembaga yang ditunjuk pemerintah.

Menurut penulis kriteria bagi BUMN yang akan diberi hak monopoli harus dilihat dari :

(1) Maksud dan tujuan berdirinya BUMN yakni apakah untuk memberikan pelayanan kepada masyarakat atau mencari keuntungan semata. Jika maksud dan tujuan untuk memberikan pelayanan kepada masyarakat maka BUMN tersebut berhak untuk diberi hak monopoli. Hal ini perlu dipertegas karena berkaitan dengan;

(2) Bentuk BUMN yaitu Perum atau Pesero. Keduanya punya kekhususan yang satu lebih cenderung mencari keuntungan artinya BUMN seperti ini tidak perlu diberi hak monopoli. Hal Ini dimaksudkan agar BUMN ini dapat berkompetisi di pasar tanpa adanya hak khusus sehingga pelaku usaha yang bukan BUMNpun dapat merasakan keadilan dalam persaingan usaha. Sedangkan yang melaksanakan pelayanan publik tetap berkonsentrasi untuk mengelola cabang-cabang produksi yang penting dan menguasai hajat hidup orang banyak demi kesejahteraan masyarakat dan :

(3) Persentase kepemilikan saham. Sebaiknya BUMN yang hendak diberi hak monopoli jumlah saham yang dimiliki oleh negara adalah seratus persen (Perum) sedangkan kepemilikan saham dibawah itu tidak diberi hak monopoli (Pesero). Dengan jumlah saham seratus persen maka dari sisi pertanggung jawab keuangan dapat menggunakan sistem yang di pakai oleh APBN. Sebaliknya yang kepemilikan sahamnya tidak seratus persen dan dapat go public (Pesero) pertanggung jawabannya menggunakan sistem pengelolaan koorporasi dan tunduk pada UndangUndang Perseroan Terbatas.

Keistimewaan yang diberikan oleh UU Anti Monopoli kepada BUMN seharusnya 
bisa dimanfaatkan dengan lebih baik lagi. Pasal 51 UU Anti Monopoli seharusnya dijadikan alat untuk dapat menghantarkan BUMN menjadi suatu badan usaha yang memiliki daya saing global yang berkedudukan satu level di atas badan usaha lainnya yang tidak memiliki keistimewaan tersebut. Hal yang seharusnya adalah bahwa BUMN sebagai salah satu tulang punggung perekonomian (aset produktif yang dimiliki oleh pemerintah) diharapkan mampu memberikan kontribusi positif bagi pemerintah dalam bentuk dividen dan pajak yang dapat meningkatkan kesejahteraan rakyat. Pasal 51 UU sudah seharusnya dijadikan senjata untuk menuju kepada suatu keberhasilan, tidak lagi dijadikan payung untuk menjalankan praktik bisnis yang menyimpang dari peraturan perundangundangan yang berlaku.

Namun semua itu kembali lagi pada kemauan BUMN untuk menjalankan praktik bisnis modern sehingga potensi dapat diubah menjadi realitas. BUMN harus berbenah dan brubah di segala bidang. Harus diupayakan adanya perubahan BUMN dari organisai birokrasi menjadi organisasi korporasi. BUMN harus sungguh-sungguh mau melepaskan segala atribut dan kebiasaan lama yang ada untuk kemudian bertransformasi mengubah diri menjadi suatu lembaga bisnis yang modern dengan pengelolaan secara profesional

\section{Badan Usaha Milik Negara Bertujuan Sebesar-besarnya Kemakmuran Rakyat}

Muhamad Hatta ${ }^{10}$ menjelaskan bahwa apa sebenarnya diamanatkan oleh proklamasi dan konstitusi kepada kita semua bahwa mengenai masalah perekonomian kita itu, yaitu tidak lain dan tidak bukan suatu susunan perekonomian Indonesia, yang kemakmuran rakyat sentris, yaitu yang mendahulukan tercapainya kemakmuran rakyat, di atas mana dapatlah dibangun berangsur-angsur segi dan bidang lain

10 Todung Mulia Lubis, 1987, hal 60 daripada kehidupan rakyat. Bahwasanya kemakmuran rakyat tarcakup rakyat banyak dan tidak hanya minoritas elit yang menjadi dasar dan tujuan pokok UUD NRI 1945.

Ditegaskan pula bahwa segala eksplorasi dan eksplotasi segala kekayaan alam kita, minyak, gas, timah, dan sebagainya, baik yang onshore maupun offshore, di atas pantai maupun lepas pantai boleh saja dikerjakan oleh swasta, kalau negara belum berdaya sepenuhnya, namun kesemuanya itu harus dipergunaka untuk sebesar-besarnya kemakmuran rakyat. Dan sekali-kali tidak untuk kemakmuran dan kemewahan minoritas elit yang berkuasa.

Eksistensi istilah sebesar-besarnya kemakmuran rakyat sebagai konsekuensi dari kata-kata dikuasai oleh negara dan dipergunakan (dalam Pasal 33 Ayat 3), meskipun kedua kata mempunyai arti yang berbeda, tetapi memiliki maksud dan tujuan yang sama dan saling berkaitan. Sebab dipergunakan merupakan tujuan dari kata dikuasai, sehingga keduanya mempunyai hubungan sebab akibat. Dengan demikian dapat dipahami bahwa kata dipergunakan sebagai akibat adanya penguasaan Negara. ${ }^{11}$

Kedua aspek kaidah tersebut tidak dapat dipisahkan satu sama lain, keduanya merupakan satu kesatuan sistemik, hak pennguasaan negara merupakan instrument (bersifat instrumental), sedangkan dipergunakan untuk sebesar-besarnyanya kemakmuran rakyat merupakan tujuan (objektif). ${ }^{12}$

Mendukung pendapat di atas, dalam penjelasan UU BUMN, dijelaskan bahwa memajukan kesejahteraan bagi seluruh rakyat sebagaimana diamanatkan dalam Pembukaan UUD NRI 1945 yang selanjutnya lebih rinci diatur dalam Pasal 33 UUD NRI 1945 merupakan tugas konstitusional bagi seluruh komponen bangsa. Dalam kaitan di atas, dirasa perlu utuk meningkatkan penguasaan seluruh kekuatan ekonomi nasional baik melalui

\footnotetext{
${ }^{11}$ Abrar Saleng, Op Cit, hal 37.

12 Ibid
} 
Rory J. Akyuwen, Kriteria Badan Usaha.....................

regulasi sektoral maupun melalui kepemilikan Negara terhadap unit-unit usaha tertentu dengan maksud utnuk memerikan manfaat yang sebesar-besarnya bagi kemakmuran rakyat.

Dari berbagai rumusan atau pengertian mengenai BUMN, maka dapat disimpulkan bahwa BUMN mempunyai ciri khusus atau karakteristik tersendiri yaitu, memiliki dua dimensi sekaligus yaitu dimensi publik dan dimensi badan usaha. Kedua dimensi tersebut hanya terdapat atau dimiliki oleh BUMN saja oleh karena itu BUMN dalam penyelenggaraannya di samping sebagai pengemban kepentingan dan pelayanan serta pemenuhan kebutuhan rakyat banyak, juga sebagai sumber pendapatan bagi Negara. Dengan perkataan lain BUMN dengan fungsi dan karakteristiknya sebagai badan usaha jelas harus menghasilkan keuntungan (profit) akan tetapi dengan dimensi publik yang merekat padanya, maka BUMN berperan pula memainkan fungsi bukan untuk profitasi (non profit), tetapi juga mengemban tanggung jawab sosial.

Dalam PP Nomor 12 Tahun 1998 Tentang Persero dijelaskan bahwa, pada hakikatnya fungsi utama pesero adalah pemupukan dana bagi Negara ataupun sebagai alat untuk mencari sumber keuangan Negara. Dalam hubungan ini masalah penanaman kekayaan Negara dalam modal Persero sangat erat hubungannya dengan kebijakan keuangan Negara. Berdasarkan hal tersebut, maka syarat utama yang harus diperhatikan adalah penyertaan modal tersebut hanya akan dilakukan oleh Negara, jika menuntut perkiraan Persero tersebut dapat memberikan keuntungan bagi Negara. Selanjutnya dalam Pasal 2 Ayat (2) PP Nomor 3 Tahun 1983 Tentang Cara Pembinaan dan Pengawasan BUMN disebutkan pula maksud dan tujuan pendirian BUMN sebagai berikut:

1) Memberikan sumbangan bagi perkembangan perekonomian Negara pada umumnya dan penerimaan Negara pada khususnya;
2) Mengadakan pemupukan keuntungan/pendapatan;

3) Menyelenggarakan kemanfaatan umum berupa barang dan jasa yang bermutu dan memadai bagi pemenuhan hajat hidup orang banyak;

4) Menjdai perintis kegiatan-kegiatan usaha yang belum dapat dilaksanakan oleh sektor swasta dan koperasi;

5) Menyelenggarakan kegiatan usaha yang bersifat melengkapi kegiatan swasta dan koperasi dengan menyediakan kebutuahan masyarakat, baik dalam bentuk barang maupun dalam bentuk jasa dengan memberikan pelayanan yang bermutu dan memadai;

6) Turut aktif memberikan bimbingan kegiatan kepada sektor swasta khususnya pengusaha golongan ekonomi lemah dan sektor koperasi;

7) Turut aktif melaksanakan dan menunjang pelaksanaan kebijaksanaan dan program pemerintah di bidang ekonomi dan pembangunan pada umumnya.

Ditinjau dari keragaman tujuan yang hendak dicapai BUMN sebagaimana diatur dalam (Peraturan Pemerintah Nomor 3 Tahun 1983) maka secara garis besar dapat dikatakan terdapat dua peranan yang utama di dalam kegiatan usaha BUMN sebagai berikut:

1) Melaksanakan fungsi komersial dalam hal ini BUMN sebagai unit ekonomi (business entity) harus mampu memupuk dana untuk membiayai aktifitasnya baik yang bersifat rutin maupun pengembangan, oleh karena itu, dalam kegiatannya harus memperoleh laba sehingga kelanjutan hidup perusahaan dapa dijaga, atau dengan kata lain BUMN berperan sebagai pemasok dana melalui pajak dan dividen.

2) Peranan kedua adalah melaksanakan fungsi non komersial, dalam hal ini BUMN yang merupakan bagian dari aparatur Negara bertindak sebagai 
wahana pembangunan (agent of development). Berperan demikian, BUMN melaksanakan programprogram pemerintah dan atau yang diembah oleh pemerintah, yang meliputi antara lain tugas-tugas perintisan dan mendorong perkembangan usaha swata dan koperasi.

BUMN dalam melaksanakan perannya baik sebagai unit usaha maupun sebagai wahana pembangunan, dalam beberapa tahun terakhir ini telah memberikan kontribusi yang cukup besar bagi pembangunan nasional. Hal ini dapat diketahui dari kenaikan penerimaan Negara sebagaimana terlihat dalam anggaran pendapatan dan belanja Negara (APBN) yang berupa penerimaan bukan pajak yaitu dividen berupa dana pembangunan, dan bagian laba pemerintah. Kontribusi lain yang tidak kalah pentingnya adalah dalam pemanfaatan tenaga kerja yang semakin banyak yang berarti mengurangi pengangguran secara relatif.

Beberapa BUMN dapat member kontribusi kepada Negara antara lain PT Telekomunikasi Indonesia Tbk dengan asset sebesar Rp 50.283 triliun; membukukan laba sebaesar Rp 6,087 triliun; atau turun 32\% dari posisi laba tahun 2002 sebesar Rp 8,039 triliun. Meskipun PT Telkom Tbk mengalami penurunan $\mathrm{Rp} 2$ triliun, namun posisi PT Telkom Tbk masih menduduki peringkat pertama dalam perolehan laba. Dibawah PT Telkom Tbk, berturut-turut PT Bank Mandiri Tbk, dengan aset sebesar Rp 249.435 triliun perolehan laba sebesar Rp 4,86 triliun. Selanjutnya PT Bank Rakyat Indonesia Tbk dengan laba sebesar Rp 2,502 triliun, dengan asset sebesar Rp 94,709 ;triliun. ${ }^{13}$ Persoalannya apakah laba yang diperoleh sudah dirasakan oleh masyarakat atau segelintir orang saja.

Dilihat dari segi wahana pembangunan, khususnya dalam pengembangan usaha, BUMN telah banyak

13 Web kementrian BUMN pula berperan serta antara lain, menjadi perintis kegiatan-kegiatan usaha yang belum dilaksanakan oleh sektor koperasi serta menyelenggarakan kegiatan usaha yang bersifat melengkapi kegiatan koperasi dan usaha swasta. BUMN juga turut aktif dalam memberikan bantuan dan bimbingan usaha kepada sektor swasta usaha khususnya pengusaha golongan ekonomi lemah dam koperasi yang dalam hal ini BUMN lazim disebut berperan sebagai "bapak angkat".

Menurut penulis, bahwa dari dua dimensi yang harus diemban dan dijalankan oleh BUMN mengundang banyak pendapat, sekaligus mencemaskan kedua fungsi yang saling bertentangan, bahwa untuk menyatukan fungsi yang saling berbeda bahkan saling bertolak belakang tidak akan memberikan hasil yang maksimal. Dari berbagai pendangan menurut penulis tidak selalu tepat, mengingat eksistensi BUMN yang mempunyai ciri khas atau karakteristik tersendiri yang tidak dapat disamakan dengan usaha swatsa dan koperasi. Menyimak makna kehadiran BUMN berdasarkan latar belakang pendiriannya tidak semata-mata difungsikan sebagai unit ekonomi dari Negara, akan tetapi juga berfungsi sebgai penyelenggara cabangcabang produksi yang penting bagi Negara dan menguasai hajat hidup orang banyak dengan mengedepankan unsur pelayanan dan kemanfaatan umum, juga mewujudkan tanggung jawab sosial dan menunjang kebijaksanaan program pemerintah di bidang ekonomi dan pembangunan pada umumnya.

Salah satu alasan yang mendasari mengapa BUMN didirikan adalah, tidak lain untuk mencapai public purpose sebagai bagian dari dimensi publik, meskipun di dalamnya harus pula dikaitkan dengan dimensi sebagai badan usaha (enterprise) tetapi dimensi publiknya tidak hilang. Menurut hemat penulis bahwa, dengan mengacu kepada Pasal 33 ayat (2), hanya cabang-cabang yang penting dan menyangkut hajat hidup orang banyak saja yang dikuasai oleh Negara, hal ini dapat 
mengisyaratkan bahwa Negara dapat memberdayakan dan mengusahakan hanya terbatas pada asset Negara yang menjadi hajat hidup rakyat banyak saja. Untuk itu terhadap tiga ayat tersebut perlu diklarifikasi ulang mengenai interpretasi/penafsiran tentang baik terminologisnya maupun subtansi filosofisnya sehingga menjadi jelas antara, mana yang haru dikelola oleh Negara dan mana yang boleh diswastakan atau mana yang dikoperasikan, mana yang harus dan cukup dikelola dalam bentuk atau usaha jawatan, mana yang diperusahaan umum dan selebihnya mana yang harus atau boleh di PT Persero.

Permasalahan dari uraian di atas adalah tidak jelasnya penilaian yang dilakukan oleh pemerintah dengan menyamaratakan semua jenis BUMN, padahal untuk BUMN perjan dan perum, provitisasi bukanlah tujuan utama dari usahanya yang penting bagaimana jasa pelayanan kepada publik diberikan secara optimal, dengan harga yang layak, selain itu BUMN harus memperhitungkan berbagai biaya produksi, efisiensi, memperoleh laba agar dapat membiayai dirinya untuk dapat bertahan.

Penjabaran lebih lanjut tentang usaha BUMN persero yang telah diatur melalui Peraturan Pemerintah Nomor 12 Tahun 1998 tentang perusahaan perseroan dlam ketentuan Pasal 4 ayat (1) disebutkan maksud dan tujuan pendirian BUMN persero adalah, menyediakan barang dan jasa yang bermutu tinggi dan berdaya saling kuat baik di pasar dalam negeri maupun internasional serta memupuk keuntungan guna meningkatkan nilai perusahaan. Demikian pula dalam Pasal 12 UU BUMN tentang maksud dan tujuan pendirian persero adalah menyedaiakan barang dan atau/jasa yang bermutu tinggi dan berdaya saling kuat. Dari ketentuan ini jelas terlihat bahwa maksud dan tujuan utama didirikannya BUMN persero tidak lain adalah, menyediakan barang dan jasa bagi masyarakat serta diarahkan untuk memupuk keuntungan.
Berbeda halnya dengan kedua bentuk usaha BUMN lainnya, yakni perjan yang dikhususkan untuk mengelolah dan melayani kebutuhan yang menyangkut hajat hidup orang banyak dan tidak diarahkan untuk memperoleh keuntungan. Sedangkan perum sebagai perusahaan yang dapat menutup operasinya dengan memperoleh keuntungan, tetapi bukan menjadi tujuan utamanya.

Berbeda dengan BUMN persero yang diarahkan untuk memperoleh keuntungan dalam arti, karena baiknya pelayanan dan diberikan dan pembinaan organisasi yang baik, efektif, efisien, dan ekonomis secara business zakeliijk, cost accounting principles, management efecitiveness dan pelayanan umum yang baik dan memuaskan dengan memperoleh surplus atau laba. Status hukumnya sebagai hukum perdata, yang terbentuk Perseroan Terbatas. Hubungan-hubungan usahanya diatur menurut hukum perdata, yang berbentuk perseroan terbatas, pengaturannya tunduk pada undang-undang Perseroan Terbatas. Modal BUMN persero balik seluruhnya atau sebagian merupakan milik Negara dari kekayaan Negara yang dipisahkan, dipisahkan dengan demikian dimungkinkan adanya joint atau mixed enterprise dengan swasta (nasional dan atau asing) dengan adanya penjualan saham-saham perusahaan milik Negara.

Berdasarkan uraian di atas menurut penulis, dalam ketentuan mengenai BUMN persero tidak ditegaskan mengenai bidang usaha apa yang harus diusahakan oleh BUMN persero, akan tetapi dalam ketentuan Pasal 4 ayat (2) hanya dikemukakan bahwa, BUMN persero dengan sifat usaha tertentu dapat melaksanakan penugasan khusus untuk menyelenggarakan fungsi kemanfaatan umum, dengan tetap memperhatikan maksud dan tujuan kegiatan sebagaimana dimaksud dalam ketentuan Pasal 4 ayat (1) di atas. Dalam bagian ketentuan tersebut dikemukakan pemerintah dapat pula menugaskan suatu BUMN persero untuk melaksanakan fungsi 
pelayanan umum, termasuk dalam fungsi tersebut adalah pelaksaan program kemitraan dan pembinaan usaha kecil dan koperasi.

Dari uraian di atas dapat dilihat juga bahwa, walaupun BUMN persero pengaturannya tunduk pada undang-undang yang mengatur semua badan usaha yang berbentuk perseroan terbatas dimana tujuan utamanya adalah memupuk keuntungan, namun BUMN tetap tunduk pada UU BUMN yang mengatur khusus (bersifat lex specialis) tentang BUMN sebagai perusahaan Negara tetap melaksanakan pelayanan umum, persero dapat diberikan tugas khusus dengan memperhatikan prinsip-prinsip pengelolan yang sehat yang keduanya tetap bertujuan untuk sebesarbesarnya kemakmuran rakyat

\section{PE N U T U P}

Berdasarkan Hasil Penelitian dan Pembahasan yang telah diuraikan dalam Bab IV sebelumnya, maka peneliti dapat menarik kesimpulan sebagai berikut :

1) Hakekat keberadaan Badan Usaha Milik Negara dalam perspektif hukum persaingan usaha sebagai instrument dari negara untuk berperan dalam perekonomian dan peran ini dalam pelaksanaannya belum sesuai dengan apa yang dicita-citakan oleh UUD NRI Tahun 1945.

2) Kedudukan Hak Monopoli Badan Usaha Milik Negara dalam perspektif hukum persaingan usaha merupakan hak khusus yang diberikan kepada BUMN untuk memainkan peranan sebagai penyeimbang dalam persaingan usaha. Namun pemberian hak tersebut dalam pelaksanaanya tidak mencerminkan persaingan usaha yang sehat sesuai dengan apa yang diatur dalam UU RI Nomor 5 Tahun 1999 tentang Larangan Praktik Monopoli dan Persaingan Usaha Tidak Sehat.
3) Kriteria Badan Usaha Milik Negara yang diberikan hak monopoli dalam perspektif hukum persaingan usaha seharusnya diserahkan kepada BUMN non profit seperti Perusahaan Jawatan (Perjan) jika dikaitkan dengan cabangcabang yang penting bagi negara dan yang menguasai hajat hidup orang banyak

\section{DAFTAR PUSTAKA}

Abrar Saleng. Hukum Pertambangan. UII Press. Jogjakarta. 2004.

Aminuddin Ilmar. Privatisasi BUMN di Indonesia. Hasanuddin University Press. Makasar. 2004.

Astim Riyanto, Teori Konstitusi, Yapemdo, Bandung. 2000.

Donald. J. Moon. The Future of Welfare State. England-The USA-Australia. 1964.

Friedman. Milton. Monopoly and The Social Responbility of Business an labour. In: Edwin Mansfield (ed). Monopoly Power and Economic Performance An Introduction To A Current Issue of Public Policy. W. W. Norton. New York. 1994.

John Rawls, A Theorie of Justice ; Teori Keadilan, dasar-Dasar Filsafat Politik untuk Mewujudkan Kesejahteraan Sosial dalam Negara, Pustaka Pelajar, Yogyakarta, 2006.

Johnny Ibrahim, Hukum Persaingan Usaha: Filosofi, Teori dan Implikasi Penerapannya di Indonesia, Bayu Media Publishing, Malang. 2007.

Jimmly Asshiddiqie. Konstitusi dan Konstitusionalisme Indonesia. Menuju Negara Hukum yang Demokratis. Konstitusi Ekonomi.Konstitusi Pers. Kompas Media Nusantara. Jakarta. 2010.

Menuju Negara Hukum yang Demokratis, Bhuana Ilmu Populer, Jakarta. 2008,

Kementrian BUMN. Target Kinerja BUMN. 
Proyeksi Kinerja dan Agenda Implementasi Program. Master Plan BUMN Tahun 2002-2006. Jakarta, 2002.

Marthen Arie, Prinsip-Prinsip Hukum dalam Penanaman Modal, Arus Timur, Makassar. 2012.

Susanti Adi Nugroho. Hukum Persaingan Usaha di Indonesia Dalam Teori Praktik Serta Penerapan Hukumnya. Kencana Prenada Media Group. Jakarta. 2012.

T. Mulya Lubis. Hukum dan Ekonomi. Sinar Harapan Jakarta. 1992.

Tony Prasentiantono. BUMN Indonesia.PT Elex Media Komputindo. Jakarta. 2005.

Utrecht. Pengantar Hukum Administrasi Negara Indonesia. Unpad. Bandung. 1960.

Velasquez. Manuel G. Businness Ethics : Concept and cases.Singapore: Prentice-Hall. 1997.

W. Friedmann, The States and The Rule of Law in a Mixed Economy, Steven and Son, London. 